\title{
Manipulative experiments demonstrate how long-term soil moisture changes alter controls of plant water use
}

\section{Grossiord, Charlotte}

2018-08

Grossiord , C , Sevanto , S , Limousin , J-M , Meir , P , Mencuccini , M , Pangle , R E , Pockman , W T , Salmon , Y , Zweifel , R \& McDowell , N G 2018 , ' Manipulative experiments demonstrate how long-term soil moisture changes alter controls of plant water use ' , Environmental and Experimental Botany , vol. 152 , pp. 19-27 . https://doi.org/10.1016/j.envexpbot.2017.12.0

http://hdl.handle.net/10138/307777

https://doi.org/10.1016/j.envexpbot.2017.12.010

cc_by_nc_nd

acceptedVersion

Downloaded from Helda, University of Helsinki institutional repository.

This is an electronic reprint of the original article.

This reprint may differ from the original in pagination and typographic detail.

Please cite the original version. 


\section{Abstract}

22 Tree transpiration depends on biotic and abiotic factors that might change in the future, including

23 precipitation and soil moisture status. Although short-term sap flux responses to soil moisture and

24 evaporative demand have been the subject of attention before, the relative sensitivity of sap flux to these

25 two factors under long-term changes in soil moisture conditions has rarely been determined

26 experimentally. We tested how long-term artificial change in soil moisture affects the sensitivity of tree-

27 level sap flux to daily atmospheric vapor pressure deficit (VPD) and soil moisture variations, and the

28 generality of these effects across forest types and environments using four manipulative sites in mature

29 forests. Exposure to relatively long-term (two to six years) soil moisture reduction decreases tree sap

30 flux sensitivity to daily $V P D$ and relative extractable water ( $R E W$ ) variations, leading to lower sap flux

31 even under high soil moisture and optimal $V P D$. Inversely, trees subjected to long-term irrigation

32 showed a significant increase in their sensitivity to daily $V P D$ and $R E W$, but only at the most water-

33 limited site. The ratio between the relative change in soil moisture manipulation and the relative change

34 in sap flux sensitivity to $V P D$ and $R E W$ variations was similar across sites suggesting common

35 adjustment mechanisms to long-term soil moisture status across environments for evergreen tree species.

36 Overall, our results show that long-term changes in soil water availability, and subsequent adjustments

37 to these novel conditions, could play a critical and increasingly important role in controlling forest water 38 use in the future.

40 Keywords: acclimation, climate change, drought, irrigation, sap flux, vapor pressure deficit, water use. 
1 Manipulative experiments demonstrate how long-term soil moisture changes alter controls of

2 plant water use

4 Charlotte Grossiord $^{1 *}$, Sanna Sevanto ${ }^{1}$, Jean-Marc Limousin ${ }^{2}$, Patrick Meir $^{3,4}$, Maurizio Mencuccini ${ }^{5,6}$,

5 Robert E. Pangle ${ }^{7}$, William T. Pockman ${ }^{7}$, Yann Salmon ${ }^{4,8}$, Roman Zweifel $^{9}$, Nate G. McDowell ${ }^{10}$

$7 \quad{ }^{1}$ Earth and Environmental Sciences Division, Los Alamos National Laboratory, Los Alamos, NM $8 \quad 87545$, USA

$9{ }^{2}$ CNRS, UMR5175 Centre d'Ecologie Fonctionnelle et Evolutive CEFE, Montpellier Cedex 5, France

$10{ }^{3}$ Research School of Biology, Australian National University, Canberra, Australia

$11{ }^{4}$ School of GeoSciences, University of Edinburgh, Edinburgh, UK

$12{ }^{5}$ ICREA, Pg. Lluís Companys 23, 08010 Barcelona, Spain

$13{ }^{6}$ CREAF, c/o UAB, Cerdanyola del Valles 08193, Barcelona, Spain

$14{ }^{7}$ Department of Biology, MSC03 2020, 1 University of New Mexico, Albuquerque, New Mexico 8713115 0001, USA

$16{ }^{8}$ Department of Physics, University of Helsinki, Helsinki, Finland

$17{ }^{9}$ Swiss Federal Institute for Forest, Snow and Landscape Research, (WSL), Birmensdorf, Switzerland $18{ }^{10}$ Earth Systems Science Division, Pacific Northwest National Laboratory, Richland, WA 99354, USA 19

20 *Corresponding author: Charlotte Grossiord, cgrossiord@lanl.gov, +1 505-303-9159 
42 Abbreviations

$43 \quad F_{D}=$ mean daily sap flux density $\left(\mathrm{g} \mathrm{m}^{-2} \mathrm{~s}^{-1}\right)$

$44 L A I=$ leaf area index $\left(\mathrm{m}^{2} \mathrm{~m}^{-2}\right)$

$45 R E W=$ relative extractable water (unitless)

$46 V P D=$ vapor pressure deficit $(\mathrm{kPa})$

47 


\section{$48 \quad$ Highlights}

49 - How long-term soil moisture change affects the sensitivity of transpiration to environmental

50 variability is unknown.

51 - Exposure to long-term soil moisture reduction decreased sap flux sensitivity to $V P D$ and $R E W$.

52 - Long-term irrigation increased sap flux sensitivity to $V P D$ and $R E W$ but at highly water-limited

$53 \quad$ sites only.

54 - Relative sensitivity to $V P D$ and $R E W$ is generalizable across forest types suggesting common adjustment mechanisms to soil moisture status. 


\section{Introduction}

Recent work has shown that plant transpiration could account for up to $90 \%$ of terrestrial evapotranspiration (Jasechko et al., 2013), making vegetation a dominant force in the global water cycle. Transpiration from forest ecosystems alone contributes between 50\% and 70\% to terrestrial evapotranspiration (Schlesinger and Jasechko, 2014). Climate-related shifts in forest transpiration could thus have large impacts on the global water cycle including modification in precipitation, groundwater recharge, renewable fresh water, increasing soil erosion, and feedbacks on (micro) climate. Average temperature at the world's surface has been steadily rising since the mid-50s (IPCC, 2014). Warmer air increases vapor pressure deficit $(V P D)$ and induces higher evaporation from land surfaces including transpiration from plants (Hardwick et al., 2010). Simultaneously, the risk for severe and extended droughts is increasing (Williams et al., 2013; Cook et al., 2015; Roderick et al., 2015).

At hourly to daily scales, tree-level sap flux primarily results from the driving force for transpiration (radiation, VPD and wind), and hydraulic and stomatal conductance of the trees (Oren et al., 1999). Without stomatal control, tree-level transpiration increases progressively with rising $V P D$ as a

71 consequence of the atmosphere becoming less moisture saturated. As VPD increases, stomata respond

72 via an exponential decrease in stomatal conductance (Lange et al., 1971; Monteith, 1995). Consequently,

73 when high $V P D$ is reached $(\approx 2.5 \mathrm{kPa}$, species-specific $)$, stomata start modulating the transpiration flux

74 and thus tree-level transpiration starts dropping due to partial stomatal closure. Therefore, the response

75 of tree-level transpiration to $V P D$ can be expressed as a parabolic equation (Fig. 1) (Monteith, 1995). By

76 closing their stomata to avoid critically high sap flux rates and impacts on embolism, trees can avoid

77 excessive damages to their hydraulic system (Saliendra et al., 1995). At daily or longer time scales, tree-

78 level sap flux regulation is also largely controlled by soil moisture variation. Tree responses to soil water

79 availability are triggered by a chemical signal originating from the roots exposed to dry soil (see reviews 
80 by Davies and Zhang, 1991; Davies et al., 1994). Strong relationships have already been established

81 between soil moisture (or water stress indexes) and tree-level sap flux enabling the incorporation of sap

82 flux responses to short-term precipitation change in several climate-vegetation models so far (e.g. Sala

83 and Tenhunen, 1996; Granier et al., 1999; Verhoef et al., 2014; De Cáceres et al., 2015).

84 Although rapid sap flux responses to soil moisture and evaporative demand have been the subject of

85 attention before, the relative sensitivity of sap flux to these two factors under long-term precipitation and

86 soil moisture change has rarely been determined experimentally (but see Grossiord et al., 2017).

87 However, to maintain integrity of water resources, and improve global predictions it is essential to

88 determine how these two drivers will influence forest transpiration in the long-term under projected

89 climate. Plants are known to have a wide range of active adjustment strategies to deal with long-term

90 exposure to changing soil moisture, including physiological and structural adjustments (Chaves et al.,

91 2002) directly influencing sap flux regulation. Under drier soil conditions, plants often undergo

92 adjustments that are directed toward a water saving strategy to limit excessive water loss (Ogaya and

93 Peñuelas, 2003; Leuzinger et al., 2005; Brando et al., 2008). For instance, trees may produce conducting

94 elements with reduced lumen diameters (Hacke and Sperry, 2004; Fonti and Jansen, 2012; Grossiord et

95 al., 2017), which can result in reduced sensitivity to short-term soil moisture variation (i.e. reduced sap

96 flux under both high and low soil water availabilities because of higher flow resistance, Fig. 1). Long-

97 term soil moisture reduction may also result in changes in stomata density (Luomala et al., 2005), or in

98 the synthesis of chemical signals inducing stomatal closure (Bartlett et al., 2012; Meinzer et al., 2014),

99 which can decrease the sensitivity of trees to evaporative demand and result in reduced sap flux, even

100 under optimal $V P D(\approx 1.5 \mathrm{kPa})$ (Fig. 1) (Grossiord et al., 2017).

101 Most of our knowledge on tree responses to climate variability is based on studies with potted plants

102 or seedlings under common garden conditions, which may not represent the true responses of mature 
103 forests (Poorter et al., 2012; Rigling et al., 2013; Herzog et al., 2014). Manipulative field experiments on

104 mature individuals are one way to decipher ecosystem sensitivity to possible precipitation change, but 105 only a few experiments have been established in natural forests to date (Knapp et al., 2016). The lack of 106 experiments in natural conditions is partially related to the obvious technical limitations and the 107 financial costs associated with large-scale climate manipulation but also legal restrictions that can occur 108 in natural areas (Kayler et al., 2015). Such experiments have however great value as, contrary to studies 109 conducted along environmental gradients, they provide the ability to expose plants to environmental 110 conditions they would not experience otherwise (i.e. broadening of environmental conditions), isolate 111 mechanistic functions and identify threshold responses necessary for global predictions (Kayler et al., 112 2015; Estiarte et al., 2016; Knapp et al., 2016).

113 Here we tested how long-term (multi-year) artificial change in incoming precipitation (i.e. increasing 114 or reducing long-term soil water availability) influences the sensitivity of tree sap flux to daily $V P D$ and 115 soil moisture variations, and the generality of these effects across four forest types and environments 116 using four manipulative sites in natural and mature forests in the USA and Europe. We hypothesized 117 that:

118 (1) changes in long-term soil moisture would modify the sap flux sensitivity of trees to 119 environmental variability with trees subjected to reductions in soil water availability showing 120 decreased sap flux sensitivity to soil moisture and $V P D$ variation while trees exposed to 121 increased soil moisture would show an enhanced sensitivity to the same factors, both because of 122 long-term adjustments in their physiology and structure (Fig. 1),

123 (2) changes in sap flux sensitivity to soil moisture and $V P D$ variation would vary across climatic and 124 environmental conditions, and for various forest types as tree species have different inherent 
responses to climatic variations (e.g. iso- and anisohydric strategies) and have adapted to their 126 local climate (e.g. long-term structural and physiological adjustments). 


\section{Materials and methods}

\subsection{Experimental sites}

We used data collected from mature forest plots in four regions covering a large gradient of environmental and climatic conditions and representing three major forest types (Fig. S1). The focal

131 regions are located in France (i.e. Mediterranean evergreen forest: the Puechabon site, PUE hereafter), the United States (i.e. two semi-arid forest types: the SUMO and Sevilleta sites, SUM and SEV

133 hereafter, respectively) and Switzerland (i.e. dry Mountainous coniferous forest: the Pfynwald site, PFY 134 hereafter). The Mediterranean evergreen forest is dominated by evergreen holm oak (Quercus ilex L.). 135 The dry Mountainous coniferous forest type is characterized by the dominance of Scots pine (Pinus 136 sylvestris L.) with pubescent oak (Quercus pubescens Willd.) mainly in the understory at the Swiss site.

137 The two semi-arid forest sites occur in high elevation deserts with the vegetation dominated by 138 evergreen junipers (Juniperus monosperma (Engelm.) Sarg.) and piñon pines (Pinus edulis Engelm.).

139 The target tree species pool varied depending on the site, going from one species in the PUE and PFY 140 sites to two species in the SEV and SUM sites (Table 1). Climatic conditions (rainfall, air temperature, 141 atmospheric humidity, solar radiation, wind speed) were measured continuously and recorded by a 142 weather station at each site (Fig. 2, see Table 1 for references). Climatic conditions were measured at 1$1433 \mathrm{~m}$ above ground in inter-canopy areas in all sites. Stand properties (leaf area index (LAI), basal area $144(B A)$, tree height, soil depth, soil type) were taken from previous studies conducted at the same sites (see 145 Table 1 for more details on site characteristics).

\subsection{Soil moisture manipulation}

All sites were subjected to precipitation manipulation influencing available soil moisture (i.e.

149 reduction, addition or both) ranging from $-90 \%$ to $+80 \%$ (Table 1 ). A control treatment (i.e. ambient 
150 precipitation) was included in each site and located near the soil moisture manipulation treatments (see

151 more details in Table 1). At the SUM site, the treatments could not be replicated because of logistical

152 and financial constraints, but the design is similar to other replicated large-scale ecosystem manipulation

153 experiments (e.g. Likens et al., 1970), whose strength is acknowledged, especially where large treatment

154 effects are expected (Pangle et al., 2012). In three sites (PUE, SEV and SUM), incoming precipitation

155 was reduced (-30\% to $-90 \%)$ by using systems of plastic panels and plastic-lined guttering installed at a

156 height between 0.5 and $2 \mathrm{~m}$, depending on the site. In two sites (SEV and PFY), soil moisture was

157 artificially increased by $+35 \%$ to $+80 \%$ using water applied via sprinklers at $1 \mathrm{~m}$ or $6 \mathrm{~m}$ above ground

158 for the PFY and SEV site, respectively (see Table 1 for site-specific references).

\subsection{Sap flux measurements}

161 At all sites tree sap flux density $\left(F_{D} ; \mathrm{g} \mathrm{m}^{-2} \mathrm{~s}^{-1}\right)$ was measured with the thermal dissipation method

162 (Granier, 1987) during one growing season of different years (see Table 1 for year selection in each

163 site). Two probes (10- or 20-mm long depending on the site and the species) were installed under the

164 bark and the cambium at 0.8 to $1.3 \mathrm{~m}$ aboveground with a $10 \mathrm{~cm}$ vertical spacing between probes. This

165 height was necessary to minimize thermal disturbance from ground heating. All sensors were covered

166 with reflective insulation to reduce the risk of direct sunlight causing thermal gradients. $F_{D}$ was

167 calculated following the equation proposed by Granier (1987). In each site between 11 and 42 dominant

168 trees were selected for the sap flux measurements (see Table 2 for tree characteristics). Methods used for

169 determining sapwood depth and appropriate corrections for radial variations in sap flux density at each

170 site are provided in Limousin et al., 2009; Pangle et al., 2015; Grossiord et al., 2017 and Mencuccini et

171 al., 2017. 


\section{3}

174

175

176

177

178

179

180

181

182

183

184

185

186

187

188

189

190

191

192

193

194

195

\subsection{Water balance modeling}

As a measure of soil water availability, we estimated the daily relative extractable water (REW, unitless, varying between 0 and 1) over the whole root zone at each site and for each treatment using the forest water balance model BILJOU (Granier et al., 1999) (Fig. 3). This model predicts temporal variations in soil water content and assesses the water stress conditions experienced by trees at a given day. In this model, the input variables required are daily meteorological data (precipitation, global radiation, air temperature and humidity, wind speed), soil water holding capacity, soil depth, soil bulk density and leaf area index $(L A I)$. The soil parameters were either directly measured or estimated at each site and provided by the site managers. $R E W$ represents the ratio between available soil water and maximum extractable water over the whole root zone and varies between 1 (i.e. field capacity) and 0 (i.e. permanent wilting point) (Granier et al., 1999). Although the BILJOU model has been validated at the SUM site (Grossiord et al. 2016b), it is important to note that $R E W$ predictions are subject to uncertainties at the SEV, PUE and PFY sites as the model has not been directly validated for these sites.

Simulations of $R E W$ with the BILJOU model were performed online (https://appgeodb.nancy.inra.fr/biljou/, Fig. 3).

Artificial manipulation of incoming precipitation based on the soil surface covered by the plastic guttering or the percentage of water added relative to ambient precipitation was similar to the relative changes in $R E W$ between ambient and treatment conditions (Fig. S2). This observation suggests that the imposed treatments were reflected in actual reductions and additions of water experienced by the trees.

Only the PFY site diverged from the 1:1 line (Fig. S2). As soil moisture conditions were already high at this site relative to other sites, an $80 \%$ precipitation addition resulted only in a $19 \%$ increase in $R E W$ relative to ambient conditions (Fig. S2). 


\subsection{Statistical analyses}

197 All analyses were performed using the software R (3.2.1, R Development Core Team 2015). As $198 R E W$ is estimated at daily time scales, we calculate the daily average in sap flux density $\left(F_{D}\right)$ for each 199 tree and daily average in $V P D$ by excluding nighttime values (i.e. values occurring when global 200 radiation $<10 \mathrm{~W} \mathrm{~m}^{-2}$ ).

201 To determine how soil moisture manipulation influenced the sensitivity of sap flux to evaporative 202 demand, several equations were tested to relate $F_{D}$ to daily $V P D$ variations including linear, exponential, 203 logarithmic and parabolic equations. Parabolic equations showed the best fit for all trees (i.e. highest $204 \mathrm{R}^{2}$ ), and were fitted to individual trees $F_{D}$ and $V P D$ relationships, similarly to Grossiord et al., (2017):

$$
F_{D}=a V P D^{2}+b V P D
$$

Adjustments to variations in $V P D$ are expected to manifest as shifts in optimal $V P D$ for transpiration to maintain high carbon uptake under drier atmospheric conditions (Grossiord et al., 2017, corresponding to the location of the vertex, $V P D_{\text {opt }}, \mathrm{kPa}$ ). In contrast, adjustments to soil moisture changes, as determined in this study, are expected to be reflected in the maximum $F_{D}$ reached at optimal VPD (Fig.
1) (Grossiord et al., 2017, $\left.F_{D M a x}, \mathrm{~g} \mathrm{~m}^{-2} \mathrm{~s}^{-1} / \mathrm{kPa}\right) . F_{D M a x}$ was thus extracted for individual trees (i.e.

ambient and manipulative treatments) from the fitted relationships of equation (1) by calculating the location of the vertex (h) and inserting it back to equation [1]:

Analyzing how precipitation manipulation influenced the sensitivity of transpiration to soil moisture was done by testing the same equations (i.e. linear, exponential, logarithmic and parabolic)

216 between $F_{D}$ and daily $R E W$. Linear equations showed the best $\mathrm{R}^{2}$ for all trees and were fitted to 217 individual trees $F_{D}$ and $R E W$ relationships following: 
219 The sensitivity of $F_{D}$ to $R E W$ variations, corresponding to the slope of the relationship $\left(S_{R E W}, \mathrm{~g} \mathrm{~m}^{-2} \mathrm{~s}^{-1}\right.$, 220 i.e. corresponding to the $b$ factor), was extracted for individual trees from the fitted relationships. We 221 used different analyses for $V P D$ and $R E W$ transpiration sensitivities because these two variables were 222 highly independent (correlation coefficient $=0.15$ ). However it is important to note that effects related to $223 V P D$ and $R E W$ are not easily separable in natural manipulative experiments and thus results have to be 224 interpreted with caution.

225 All relationships were fitted using the package $n l s$. Differences in $F_{D M a x}$ and $S_{R E W}$ between 226 treatments and sites were determined through two-way ANOVA where treatments, sites and their 227 interaction were used as fixed effects. For all tests, tree identity was treated as random effect. Post-hoc 228 analysis was performed with Tukey's HSD test to determine differences between treatments. An alpha 229 critical value of $\alpha=0.05$ was used to determine statistical significance. 


\section{Results}

\subsection{Climatic conditions}

All four sites were characterized by contrasting soil water availability under ambient conditions with the SEV site being the driest and the PFY site the wettest (mean yearly REW: SEV $<\mathrm{SUM}<\mathrm{PUE}<$

PFY, Fig. 3). Similarly, evaporative demand was highest at the SEV site (maximum daily average VPD of $3.4 \mathrm{kPa}$ ) and lowest at the PFY site (maximum daily average $V P D$ of $2.0 \mathrm{kPa}$ ) (mean yearly $V P D$ :

\subsection{Effect of precipitation manipulation on $F_{D}$ sensitivity to $V P D$}

We observed a significant parabolic $F_{D}$ response to daily variations in $V P D$ in all sites and treatments (Fig. 4). A significant effect of precipitation manipulation was found for the sap flux sensitivity to $V P D$, i.e. maximum $F_{D}$ at optimal $V P D\left(F_{D M a x}\right.$, optimal $\left.V P D \approx 2 \mathrm{kPa}\right)(P<0.001)$ with the lowest $F_{D M a x}$ found under precipitation reduction and highest $F_{D M a x}$ found under precipitation addition (Fig. 4). $F_{D M a x}$ significantly varied between sites $(P<0.001)(\mathrm{SUM}<\mathrm{SEV}<\mathrm{PUE}<\mathrm{PFY})$ but the treatment* site interaction was not significant suggesting that all sites responded similarly to precipitation manipulation (Fig. 5). A strong relationship was found between the relative change in $F_{D M a x}\left(\right.$ i.e. $F_{D M a x}$ in the manipulative treatment/ $F_{D M a x}$ in ambient conditions) and the relative change in $R E W$ ( $R E W$ in the manipulative treatment /REW in ambient conditions) across all sites (Fig. 6), suggesting similar responses in sap flux sensitivity to $V P D$ variations under long-term (two to 11 years) 253 precipitation manipulation for a large range of environmental, biotic and climatic conditions. 


\section{$254 \quad 3.3$ Effect of precipitation manipulation on $\boldsymbol{F}_{\boldsymbol{D}}$ sensitivity to $R E W$}

255 We found strong linear $F_{D}$ responses to daily $R E W$ variations in all sites and treatments (Fig. 4).

256 Precipitation manipulation significantly influenced the sensitivity of $F_{D}$ to $R E W\left(S_{R E W}\right)(P<0.001)$ with 257 the lowest $S_{R E W}$ observed under precipitation reduction and the highest $S_{R E W}$ found under precipitation 258 addition (Fig. 4). $S_{R E W}$ also varied between sites $(P=0.006)$ (Fig. 5) but the treatment*site interaction 259 was not significant suggesting that $F_{D}$ sensitivity to $R E W$ responded similarly to precipitation 260 manipulation in all sites. A strong relationship was found between the relative change in $S_{R E W}$ (i.e. $S_{R E W}$ 261 in the manipulative treatment / $S_{R E W}$ in ambient conditions) and the relative change in $R E W$ (REW in the 262 manipulative treatment / $R E W$ in ambient conditions) across all sites (Fig. 6), suggesting again similar 263 responses in sap flux sensitivity to $R E W$ variations for all the forest types and environmental conditions 264 included in this study. 


\section{Discussion}

Forest transpiration is a major component of the global water cycle and plays a significant role in trees' ability to store terrestrial carbon (Chapin et al., 1990). Long-term changes in precipitation could 269 largely impact forest services, distribution, and net primary production (Zhao and Running, 2010).

270 Several mechanisms have been proposed regarding how trees hydrologically respond to soil moisture 271 stress (McDowell et al., 2008; Adams et al., 2013) but no study has yet attempted to decipher how long272 term exposure to precipitation change, and subsequent adjustments to novel soil moisture conditions, 273 could alter the sensitivity of transpiration to environmental variability. Our analysis of sap flux 274 responses to artificial soil moisture manipulation in mature ecosystems highlights how long-term 275 adjustments to soil moisture status affect the sensitivity of trees to daily variations in evaporative 276 demand and soil water availability. Soil water content is a major limiting factor for tree sap flux on daily time-scales (Sperry et al.., 2002; Bréda et al., 2006). In the present study, we show that long-term soil moisture change could also play a critical and increasingly important role in controlling forest water use in the future. Specifically, exposure to relatively long-term (i.e. between two and six years) soil moisture reduction decreases the sensitivity of trees to daily $V P D$ and soil moisture variations (Fig. 5). As a result, trees are not able to maintain sap flux rates similar to ambient conditions during the growing season, even under high soil

284 be the consequence of several mechanistic adjustments to long-term soil moisture limitation. For 285 instance, previous work conducted in one of the focal sites showed that trees shifted their water uptake depth, sometimes to more superficial soil compartments, thereby exaggerating soil moisture constraints on sap flux (Grossiord et al., 2016b). Other key attributes impacting tree water use rates and potentially 288 the sensitivity to $V P D$ and soil moisture could be related to reductions in leaf area:sapwood area ratios 
289 (Mencuccini and Grace, 1995; Limousin et al., 2012; Togashi et al., 2015), and reduced hydraulic 290 conductance (Pangle et al., 2015; Grossiord et al., 2016a; 2017; Salomón et al., 2017) resulting from 291 xylem embolism (Sperry and Tyree, 1988). One also cannot exclude legacy effects induced by 292 prolonged soil water limitations: artificial precipitation reduction was associated with a reduced ability 293 to assimilate new carbon in all experimental sites (Limousin et al., 2010; Limousin et al. 2013;

294 Grossiord et al. 2016a). Carbon resources are required for primary survival functions such as growth and 295 defense, thus long-term soil moisture reduction could alter the susceptibility of trees to extreme events 296 and likely increase their mortality risk during consecutive droughts (Waring, 1987). On a larger scale, 297 reduced sap flux sensitivity to environmental variations during the growing season could affect both the 298 global carbon and water cycles by limiting forest evapotranspiration rates and reducing carbon storage.

Precipitation addition, and thus increased long-term soil moisture, also significantly influenced 300 the sensitivity of trees to environmental variability. At the driest site (SEV), trees showed an enhanced 301 sensitivity to $V P D$ and $R E W$ under a $35 \%$ precipitation increase (Fig. 5). As water is the main limiting 302 environmental factor for transpiration at this site, one could have expected this relatively strong adjustment response to soil moisture addition (Valladares and Percy, 2002). Among other underlying mechanisms, irrigation could have impacted tree allometry by shifting carbon investment between below- and above-ground compartments: plants growing in mesic regions, or subjected to artificial irrigation often develop a more dense and extended superficial rooting system relative to trees in arid regions or subjected to soil moisture reduction (e.g. Togashi et al., 2015). This belowground adjustment could have also occurred at the SEV site and could partially explain the high responsiveness of irrigated trees to daily $R E W$ and $V P D$ variations. In contrast, in the least water-limited site included in this study 310 (PFY), irrigation resulted in a modest increase of sap flux density (Fig. S3) and similar sensitivities to $311 V P D$ and $R E W$ variations relative to ambient conditions (Figs. 4 and 5). This response could be related 
312 to the less dry conditions at this site relative to the SEV site (Table 1) as an $80 \%$ precipitation addition at

313 the PFY site did result in a less pronounced increase in soil moisture relative to ambient conditions than

314 in the SEV site (Fig. 2). Alternatively, the discrepancy between the two irrigation sites could be partially

315 related to differences in irrigation methods: while water was added at $1 \mathrm{~m}$ above ground at the PFY site

316 (only modifying soil moisture status), irrigation was applied at $6 \mathrm{~m}$ above ground at the SEV site thereby

317 changing soil moisture and microclimatic conditions in the crown simultaneously. Interestingly, earlier

318 observations at the PFY site found significant structural aboveground adjustments to irrigation including

319 increased needle and shoot length, stand LAI (Dobbertin et al., 2010; Timofeeva et al., 2017) and water-

320 use efficiency (i.e. $\delta^{13} \mathrm{C}$, Eilmann et al., 2010) but a delay in fine root biomass production (Brunner et

321 al., 2009; Herzog et al., 2014), suggesting an immediate and a relatively higher investment in productive

322 functions rather than belowground root foraging in response to irrigation. Similar results were obtained

323 for holm oak trees along a precipitation gradient in Southern France, where the leaf area responded to

324 water availability, but not the fine root area (Martin-St Paul et al., 2013).

A key strength of the analysis conducted here is that it provides long-term sap flux adjustment

responses to soil moisture change across various temperate northern-hemisphere environments, and from

327 forest types composed of different tree species, but low species diversity. Contrary to our initial

328 hypothesis, we found a strong relationship between the relative change in soil moisture (from ambient

329 conditions) and the relative change in sap flux sensitivity to $V P D$ and $R E W$ variations (from ambient

330 conditions), suggesting similar responses to soil water availability manipulation across all sites (Fig. 6).

331 Considering the large variability in climatic, environmental and biotic conditions among sites, this

332 observation is rather surprising. We know that sap flux regulation in response to evaporative demand

333 and soil moisture is species-specific (e.g. Zweifel et al., 2009; Matheny et al., 2014), and the limited

334 number of species investigated in each site did not allow us to separate species-specific responses. One 
may expect that species with different functional strategies, particularly isohydric and anisohydric tree species, would show differential responses to $V P D$ and $R E W$ variations (e.g. Tardieu and Simonneau, 1998; Limousin et al., 2013; Garcia-Forner et al., 2016), and contrasting long-term adjustments in their physiology and structure (Grossiord et al., 2016b; Grossiord et al., 2017). Furthermore, the sites were subjected to soil moisture manipulation for different time spans before the measurements started, 340 enabling trees to adjust for more or less longer time periods to soil moisture manipulation. Trees that 341 have been subjected to longer treatment manipulation (e.g. PFY for 11 years) could have shown stronger 342 changes in sap flux sensitivity to $V P D$ and $R E W$ than trees subjected to shorter soil moisture change 343 (e.g. SEV site for two years). Indeed, several studies have suggested that structural adjustments to 344 climate change, which are more likely to impact sap flux sensitivity to environmental variability, tend to 345 be more rapid than physiological ones (Valladares et al., 2000; Fisher et al., 2007; Grossiord et al., 346 2016a). Nevertheless, as this study only included temperate-zone evergreen species, the results may 347 suggest common rapid adjustment mechanisms to long-term soil moisture status across environments for 348 leaf-persistent tree species. To further test this hypothesis, future work and manipulative experiments 349 should consider including more species from a large range of functional strategies and biomes.

The main results of the present study reinforces the idea that forest responses to climate change

351 will depend on many biotic and abiotic factors, particularly the adjustment capacity of trees to novel 352 climatic conditions. In summary, our results reveal that long-term adjustments to soil moisture will alter 353 the sap flux sensitivity to daily variations in evaporative demand and soil moisture. Climate models 354 commonly forecast an increase in precipitation in already moist regions in the next 100 years while 355 water-limited regions may experience long-term precipitation reduction (IPCC, 2014). Based on our 356 findings in dry ecosystems with experimentally lowered and increased soil water availability, this 357 suggests that trees growing in moist regions may not experience significant changes in their sensitivity 
358 to environmental variability under projected precipitation change. Inversely, this work showed that trees 359 growing in already highly water-limited regions may see significant reductions in their sensitivity to 360 evaporative demand and soil moisture variations, highlighting the potential for stronger responses to 361 precipitation change in water-limited regions. Milder and cooler environments where light, temperature 362 or nutrients are the main limiting factor for tree functioning rather than soil moisture might show 363 stronger responsiveness and adjustment capacities to other factors (Niinemets, 2010). This is in line with 364 recent work showing that forest water use is mostly dominated by soil moisture limitations in dry 365 regions and by evaporative demand in mesic ones (Novick et al., 2016). As our study only included soil 366 moisture manipulation experiments, it is difficult to conclude how long-term adjustments to other 367 climate-related stresses such as warming and subsequently rising evaporative demand may alter 368 transpiration responses to environmental variability. New long-term experiments, in different climates 369 (from dry to moist) and manipulating additional environmental factors such as temperature and $\mathrm{CO}_{2}$, are 370 urgently needed to help bring some light on tree functioning and on the longer-term adjustment potential 371 of forest ecosystems to climate change. 


\section{Acknowledgments}

374 The SUMO and SEV experiments were funded by the US Department of Energy, Office of Science, 375 Biological and Environmental Research. The SEV experiment was also supported by the resources and 376 staff of the Sevilleta LTER (funded by NSF DEB 0620482), the Sevilleta Field Station at the University 377 of New Mexico, and the US Fish and Wildlife Service, who provided access to the Sevilleta National 378 Wildlife Refuge. The Puéchabon experimental site belongs to the SOERE F-ORE-T, which is supported 379 annually by Ecofor, Allenvi and the French national research infrastructure ANAEE. Evaluations were 380 based on data from the long-term irrigation experiment Pfynwald, which is part of the Swiss Long-term 381 Forest Ecosystem Research programme LWF (www.lwf.ch) and the biological drought and growth 382 indicator network TreeNet (www.treenet.info). We are in particular grateful to Melissa Dawes and 383 Marcus Schaub who provided the soil moisture and forest structure data for the Pfynwald site, and to 384 Jean-Marc Ourcival for Puéchabon ancillary data. CG was supported by a Director's Fellowship from 385 the Los Alamos National Laboratory. YS was funded by NERC (NE/I011749/1 to MM) and the 386 academy of Finland (1284701). 


\section{References}

389 Adams, H. D., Germino, M. J., Breshears, D. D., Barron-Gafford, G. A., Guardiola-Claramonte, M., 390 Zou, C. B., \& Huxman, T. E., 2013. Nonstructural leaf carbohydrate dynamics of Pinus edulis during 391 drought-induced tree mortality reveal role for carbon metabolism in mortality mechanism. New Phyt. $392197,1142-1151$.

393 Adams, H. D., Collins, A. D., Briggs, S. P., Vennetier, M., Dickman, L. T., Sevanto, S. A., Garcia394 Forner, N., McDowell, N. G., 2015. Experimental drought and heat can delay phenological development 395 and reduce foliar and shoot growth in semiarid trees. Glob. Chan. Biol., 21, 4210-4220.

396 Bartlett, M. K., Scoffoni, C., Sack, L., 2012. The determinants of leaf turgor loss point and prediction of 397 drought tolerance of species and biomes: a global meta-analysis. Ecol. Lett. 15, 393-405.

398 Brando, P. M., Nepstad, D. C., Davidson, E. A., Trumbore, S. E., Ray, D., Camargo, P., 2008. Drought 399 effects on litterfall, wood production and belowground carbon cycling in an Amazon forest: results of a 400 throughfall reduction experiment. Philosophical Transactions of the Royal Society of London B: Biol. 401 Scie. 363, 1839-1848.

402 Bréda, N., Huc, R., Granier, A., Dreyer, E., 2006. Temperate forest trees and stands under severe 403 drought: a review of ecophysiological responses, adaptation processes and long-term consequences. 404 Ann. For. Sci. 63, 625-644.

405 Brunner, I., Graf-Pannatier, E., Frey, B., Rigling, A., Landolt, W., Dobbertin, M., 2009. Morphological 406 and physiological responses of Scots pine fine roots to water supply in a climatic dry area in 407 Switzerland. Tree Physiol. 29, 541-550.

408 Chapin, F. S., Schulze, E. D., Harold, A. M., 1990. The ecology and economics of storage in plants. 409 Ann. Rev. Ecol. Syst. 21, 423-447. 
410 Chaves, M.M., Pereira, J.S., Maroco, J., Rodrigues, M.L., Ricardo, C.P.P., Osório, M.L., Carvalho, I.,

411 Faria, T. Pinheiro, C., 2002. How plants cope with water stress in the field? Photosynthesis and growth.

412 Ann. Bot. 89, 907-916.

413 Cook, B. I., Ault, T. R., Smerdon, J. E., 2015. Unprecedented 21st century drought risk in the American 414 Southwest and Central Plains. Sci. Adv. 1, e1400082.

415 Davies, W. J., Zhang, J., 1991. Root signals and the regulation of growth and development of plants in 416 drying soil. Ann. Rev. Plant Biol. 42, 55-76.

417 Davies, W. J., Tardieu, F., \& Trejo, C. L., 1994. How do chemical signals work in plants that grow in 418 drying soil?. Plant Physiol. 104, 309.

419 De Cáceres, M., Martínez-Vilalta, J., Coll, L., Llorens, P., Casals, P., Poyatos, R., Pausas, J.G., Brotons, 420 L., 2015. Coupling a water balance model with forest inventory data to predict drought stress: the role of 421 forest structural changes vs. climate changes. Agri. For. Meteor. 213, 77-90.

422 Dobbertin, M., Eilmann, B., Bleuler, P., Giuggiola, A., Graf Pannatier, E., Landolt, W., Schleppi, P., 423 Rigling, A., 2010. Effect of irrigation on needle, shoot and stem growth in natural drought exposed 424 Pinus sylvestris forests. Tree Physiol. 30, 346-360.

425 Eilmann, B., Buchmann, N., Siegwolf, R., Saurer, M., Cherubini, P., Rigling, A., 2010. Fast response to 426 improved water availability of tree-ring width and d13C in Scots pine. Plant, Cell \& Envir. 33,1351$427 \quad 1360$.

428 Estiarte, M., Vicca, S., Peñuelas, J., Bahn, M., Beier, C., Emmett, B.A., Fay, P.A., Hanson, P.J., 429 Hasibeder, R., Kigel, J., Kröel-Dulay, G., 2016. Few multiyear precipitation-reduction experiments find 430 a shift in the productivity-precipitation relationship. Glob. Change Biol. 22, 2570-2581. 
431 Fisher, R.A., Williams, M., Costa, D., Lola, A., Malhi, Y., da Costa, R.F., Almeida, S., Meir, P., 2007.

432 The response of an Eastern Amazonian rain forest to drought stress: results and modelling analyses from 433 a throughfall exclusion experiment. Glob. Change Biol. 13, 2361-2378.

434 Fonti, P., Jansen, S., 2012. Xylem plasticity in response to climate. New Phyt. 195, 734-736.

435 Garcia-Forner, N., Adams, H.D., Sevanto, S., Collins, A.D., Dickman, L.T., Hudson, P.J., Zeppel, M.J., 436 Jenkins, M.W., Powers, H., Martínez-Vilalta, J. Mcdowell, N.G., 2016. Responses of two semiarid 437 conifer tree species to reduced precipitation and warming reveal new perspectives for stomatal 438 regulation. Plant, Cell \& Envir. 39, 38-49.

439 Granier, A., 1987. Evaluation of transpiration in a Douglas-fir stand by means of sap flow 440 measurements. Tree Physiol. 3, 309-320.

441 Granier, A., Bréda, N., Biron, P., Villette, S., 1999. A lumped water balance model to evaluate duration 442 and intensity of drought constraints in forest stands. Ecol. Model. 116, 269-283.

443 Grossiord, C., Sevanto, S., Adams, H. D., Collins, A. D., Dickman, L. T., McBranch, N., Michaletz, S. 444 T., Stockton, E. A., Vigil, M., McDowell, N. G., 2016a. Precipitation, not air temperature, drives 445 functional responses of trees in semi-arid ecosystems. Jour. Ecol. 105, 163-175.

446 Grossiord, C., Sevanto, S., Dawson, T. E., Adams, H. D., Collins, A. D., Dickman, L. T., Newman, B. 447 D., Stockton, E. A., McDowell, N. G., 2016b. Warming combined with more extreme precipitation 448 regimes modifies the water sources used by trees. New Phytol. 213, 584-596.

449 Grossiord, C., Sevanto, S., Borrego, I., Chan, A. M., Collins, A. D., Dickman, L. T., Hudson, P. J., 450 McBranch, N., Michaletz, S. T., Pockman, W. T., Ryan, M., Vilagrosa, A., McDowell, N., 2017. Tree 451 water dynamics in a drying and warming world. Plant, Cell \& Environ. DOI: 10.1111/pce.12991 
452 Hacke, U. G., Sperry, J. S., Pittermann, J., 2004. Analysis of circular bordered pit function II.

453 Gymnosperm tracheids with torus-margo pit membranes. Amer. Jour. Bot. 91, 386-400.

454 Hanson, P.J., 2000. Large-scale water manipulations. Chapter 23 in Methods in Ecosystem Science (eds 455 SalaOE, JacksonRB, MooneyHA, HowarthRW), pp. 341-352. Springer-Verlag, New York.

456 Hardwick, J., Westra, S., Sharma, A., 2010. Observed relationships between extreme sub-daily 457 precipitation, surface temperature, and relative humidity. Geophys. Res. Lett. 37.

458 Hartmann, M., Brunner, I., Hagedorn, F., Bardgett, R.D., Stierli, B., Herzog, C., Chen, X., Zingg, A., 459 Graf-Pannatier, E., Rigling, A., Frey, B., 2017. A decade of irrigation transforms the soil microbiome of 460 a semi-arid pine forest. Molecul. Ecol. doi:10.1111/mec.13995

461 Herzog, C,. Steffen, J., Graf Pannatier, E., Hajdas, I., Brunner, I., 2014. Nine Years of Irrigation Cause 462 Vegetation and Fine Root Shifts in a Water-Limited Pine Forest. PLoS ONE 9, e96321. DOI:

463 10.1371/journal.pone.0096321

464 IPCC., 2014: Climate Change 2014: Synthesis Report. Contribution of Working Groups I, II and III to 465 the Fifth Assessment Report of the Intergovernmental Panel on Climate Change [Core Writing Team, 466 R.K. Pachauri and L.A. Meyer (eds.)]. IPCC, Geneva, Switzerland, 151 pp.

467 Jasechko, S., Sharp, Z. D., Gibson, J. J., Birks, S. J., Yi, Y., Fawcett, P. J., 2013. Terrestrial water fluxes 468 dominated by transpiration. Nature 496, 347-350.

469 Kayler, Z.E., De Boeck, H.J., Fatichi, S., Grünzweig, J.M., Merbold, L., Beier, C., McDowell, N. 470 Dukes, J.S., 2015. Experiments to confront the environmental extremes of climate change. Front. Ecol. 471 Environ. 13, 219-225.

472 Knapp, A. K., Avolio, M. L., Beier, C., Carroll, C. J., Collins, S. L., Dukes, J. S., Fraser, L.H., Griffin 473 Nolan, R.J., Hoover, D.L., Jentsch, A., Loik, M. E., 2016. Pushing precipitation to the extremes in 
474 distributed experiments: recommendations for simulating wet and dry years. Glob. Change Biol. 23, $475 \quad 1774-1782$.

476 Lange, O.L., Losch, R., Schulze, E.-D., Kappen, L., 1971. Responses of stomata to changes in humidity. 477 Planta 100, 76-86.

478 Leuzinger, S., Zotz, G., Asshoff, R., Körner, C., 2005. Responses of deciduous forest trees to severe 479 drought in Central Europe. Tree Physiol. 25, 641-650.

480 Likens, G. E., Bormann, F. H., Johnson, N. M., Fisher, D. W., Pierce, R. S., 1970. Effects of forest 481 cutting and herbicide treatment on nutrient budgets in the Hubbard Brook watershed-ecosystem. Ecol. 482 Monogr. 40, 23-47.

483 Limousin, J. M., Rambal, S., Ourcival, J. M., Rocheteau, A., Joffre, R., Rodríguez-Cortina, R., 2009. 484 Long-term transpiration change with rainfall decline in a Mediterranean Quercus ilex forest. Global 485 Change Biol. 15, 2163-2175.

486 Limousin, J.M., Misson, L., Lavoir, A.V., Martin, N.K., Rambal, S. 2010. Do photosynthetic limitations 487 of evergreen Quercus ilex leaves change with long-term increased drought severity? Plant Cell and 488 Environ. 33, 863-875

489 Limousin, J.M., Rambal, S., Ourcival, J.M., Rodriguez-Calcerrada, J., Pérez-Ramos, I.M., Rodriguez490 Cortina, R., Misson, L., Joffre, R. 2012. Morphological and phenological shoot plasticity in a 491 Mediterranean evergreen oak facing long-term increased drought. Oecologia 169, 565-577. 492 Limousin, J. M., Bickford, C.P., Dickman, L.T., Pangle, R.E., Hudson, P.J., Boutz, A.L., Gehres, N., 493 Osuna, J.L., Pockman, W.T., McDowell, N.G., 2013. Regulation and acclimation of leaf gas exchange 494 in a pinon-juniper woodland exposed to three different precipitation regimes. Plant, Cell \& Environ. 36, $495 \quad 1812-1825$. 
Luomala, E., Laitinen, K., Sutinen, S., Kellomäki, S., Vapaavuori, E., 2005. Stomatal density, anatomy 497 and nutrient concentrations of Scots pine needles are affected by elevated CO2 and temperature. Plant, 498 Cell \& Environ. 28, 733-749.

499 Matheny, A.M., Bohrer, G., Vogel, C.S., Morin, T.H., He, L., Frasson, R.P.D.M., Mirfenderesgi, G., 500 Schäfer, K.V., Gough, C.M., Ivanov, V.Y. Curtis, P.S., 2014. Species-specific transpiration responses to 501 intermediate disturbance in a northern hardwood forest. Journ. Geophys. Res.: Biogeosci. 119, 22925022311.

503 Martinez-Vilalta, J., Cochard, H., Mencuccini, M., Sterck, F.J., Herrero, A., Korhonen, J.F.J., Llorens, 504 P., Nikinmaa, E., Poyatos, R., Ripullone, F., Sass-Klaassen, U., Zweifel, R., 2009. Hydraulic adjustment 505 of Scots pine across Europe. New Phytol. 184, 353-364.

506 Martin-StPaul, N.K., Limousin, J.M., Vogt-Schilb, H., Rodriguez-Calcerrada, J., Rambal, S., 507 Longepierre, D., Misson, L. 2013. The temporal response to drought in a Mediterranean evergreen tree : 508 comparing a regional precipitation gradient and a throughfall exclusion experiment. Global Change Biol. 509 19, 2413-2426.

510 McDowell, N., Pockman, W.T., Allen, C.D., Breshears, D.D., Cobb, N., Kolb, T., Plaut, J., Sperry, J., 511 West, A., Williams, D.G. Yepez, E.A., 2008. Mechanisms of plant survival and mortality during 512 drought: why do some plants survive while others succumb to drought?. New phytol 178, 719-739.

513 Meinzer, F. C., Woodruff, D. R., Marias, D. E., McCulloh, K. A., Sevanto, S., 2014. Dynamics of leaf 514 water relations components in co - occurring iso - and anisohydric conifer species. Plant, Cell \& 515 Environ. 37, 2577-2586.

516 Mencuccini, M., Grace, J., 1995. Climate influences the leaf area/sapwood area ratio in Scots pine. Tree 517 Physiol. 15, 1-10. 
518 Mencuccini, M., Salmon, Y., Mitchell, P., Holtta, T., Choat, B., Meir, P., O'Grady, A., Tissue, D.,

519 Zweifel, R., Sevanto, S., Pfautsch, S., 2017. An empirical method that separates irreversible stem radial 520 growth from bark water content changes in trees: theory and case studies. Plant, Cell \& Environ. 40, $521290-303$.

522 Monteith, J. L., 1995. A reinterpretation of stomatal responses to humidity. Plant, Cell \& Environ. 18, $523 \quad 357-364$.

524 Niinemets, Ü., 2010. Responses of forest trees to single and multiple environmental stresses from 525 seedlings to mature plants: past stress history, stress interactions, tolerance and acclimation. For. Ecol.

526 Manag. 260,1623-1639.

527 Novick, K. A., Ficklin, D. L., Stoy, P. C., Williams, C. A., Bohrer, G., Oishi, A. C., Papuga, S.A., 528 Blanken, P.D., Noormets, A., Sulman, B.N. Scott, R.L., 2016. The increasing importance of atmospheric 529 demand for ecosystem water and carbon fluxes. Nature Climate Change 6, 1023-1027.

530 Ogaya, R., Peñuelas, J., 2003. Comparative field study of Quercus ilex and Phillyrea latifolia:

531 photosynthetic response to experimental drought conditions. Env. Exp. Bot. 50, 137-148.

532 Oren, R., Sperry, J. S., Katul, G. G., Pataki, D. E., Ewers, B. E., Phillips, N., Schäfer, K. V. R., 1999.

533 Survey and synthesis of intra-and interspecific variation in stomatal sensitivity to vapour pressure 534 deficit. Plant, Cell \& Envir. 22, 1515-1526.

535 Pangle, R. E., Hill, J. P., Plaut, J. A., Yepez, E. A., Elliot, J. R., Gehres, N., Pockman, W. T., 2012. 536 Methodology and performance of a rainfall manipulation experiment in a piñon-juniper woodland. 537 Ecosphere 3, 1-20.

538 Pangle R.E., Limousin J-M, Plaut J.A., Yepez E.A., Hudson P.J., Boutz A.L., Gehres N., Pockman 539 W.T., McDowell N.G., 2015. Prolonged experimental drought reduces plant hydraulic conductance 
540 and transpiration and increases mortality in a piñon-juniper woodland. Ecol. Evol. DOI:

$541 \quad 10.1002 /$ ece3.1422.

542 Poorter, H., Fiorani, F., Stitt, M., Schurr, U., Finck, A., Gibon, Y., Pons, T. L., 2012. The art of growing

543 plants for experimental purposes: a practical guide for the plant biologist. Funct. Plant Biol. 39, 821-838.

544 R Core Team (2015). R: A language and environment for statistical computing. R Foundation for

545 Statistical Computing, Vienna, Austria. URL https://www.R-project.org/.

546 Rigling, A., Bigler, C., Eilmann, B., Mayer, P., Ginzler, C., Vacchiano, G., Weber, P., Wohlgemuth, T., 547 Zweifel, R., Dobbertin, M., 2013. Driving factors of a vegetation shift from Scots pine to pubescent oak 548 in dry Alpine forests. Global Change Biol. 19, 229-240. DOI:10.1111/gcb.12038

549 Roderick, M.L., Greve, P., Farquhar, G.D., 2015. On the assessment of aridity with changes in 550 atmospheric CO2. Water Resour. Res. 51, 5450-5463.

551 Sala, A., J. D. Tenhunen., 1996. Simulations of canopy net photosynthesis and transpiration in Quercus 552 ilex L. under the influence of seasonal drought. Agricul. For. Met. 78, 203-222.

553 Saliendra, N. Z., Sperry, J. S., Comstock, J. P., 1995. Influence of leaf water status on stomatal response 554 to humidity, hydraulic conductance, and soil drought in Betula occidentalis. Planta 196, 357-366.

555 Salomón, R.L., Limousin, J.M., Ourcival, J.M., Rodríguez-Calcerrada, J. Steppe, K., 2017. Stem 556 hydraulic capacitance decreases with drought stress: implications for modelling tree hydraulics in the 557 Mediterranean oak Quercus ilex. Plant, Cell \& Envir., DOI: 10.1111/pce.12928.

558 Schlesinger, W. H., Jasechko, S., 2014. Transpiration in the global water cycle. Agri. For. Met. 189, $559 \quad 115-117$.

560 Sperry, J.S., Tyree, M.T., 1988. Mechanism of water stress-induced xylem embolism. Plant Physiol. 88, $561581-587$. 
562 Sperry, J.S., Hacke, U.G., Oren, R., Comstock, J.P., 2002. Water deficits and hydraulic limits to leaf

563 water supply. Plant, Cell and Environ. 25, 251-263

564 Sterck, F.J., Martinez-Vilalta, J., Mencuccini, M., Cochard, H., Gerrits, P., Zweifel, R., Herrero, A., 565 Korhonen, J.F.J., Llorens, P., Nikinmaa, E., Nole, A., Poyatos, R., Ripullone, F., Sass-Klaassen, U., 566 2012. Understanding trait interactions and their impacts on growth in Scots pine branches across Europe. 567 Funct. Ecol. 26, 541-549.

568 Tardieu, F. Simonneau, T., 1998. Variability among species of stomatal control under fluctuating soil 569 water status and evaporative demand: modelling isohydric and anisohydric behaviours. Jour. Exp. Bot. $570 \quad 419-432$.

571 Togashi, H.F., Prentice, I.C., Evans, B.J., Forrester, D.I., Drake, P., Feikema, P., Brooksbank, K., 572 Eamus, D. Taylor, D., 2015. Morphological and moisture availability controls of the leaf area-to573 sapwood area ratio: analysis of measurements on Australian trees. Ecol. Evol. 5, 1263-1270.

574 Timofeeva, G., Treydte, K., Bugmann, H., Rigling, A., Schaub, M., Siegwolf, R., Saurer, M., 2017. 575 Long-term effects of drought on tree-ring growth and carbon isotope variability in Scots pine in a dry 576 environment. Tree Physiol., 1-14.

577 Valladares, F., Wright, S. J., Lasso, E., Kitajima, K., Pearcy, R. W., 2000. Plastic phenotypic response to 578 light of 16 congeneric shrubs from a Panamanian rainforest. Ecology 81, 1925-1936.

579 Valladares, F., Pearcy, R.W., 2002. Drought can be more critical in the shade than in the sun: a field 580 study of carbon gain and photo-inhibition in a Californian shrub during a dry El Niño year. Plant, Cell 581 and Environ. 25, 749-759. 
582 Verhoef, A., Egea, G., 2014. Modeling plant transpiration under limited soil water: Comparison of 583 different plant and soil hydraulic parameterizations and preliminary implications for their use in land 584 surface models. Agri. For. Met. 191, 22-32.

585 Waring, R. H., 1987. Characteristics of trees predisposed to die. Bioscience 37, 569-574.

586 Williams, A.P., Allen, C.D., Macalady, A.K., Griffin, D., Woodhouse, C.A., Meko, D.M., Swetnam, 587 T.W., Rauscher, S.A., Seager, R., Grissino-Mayer, H.D., Dean, J.S., McDowell N.G., 2013.

588 Temperature as a potent driver of regional forest drought stress and tree mortality. Nature Climate 589 Change 3, 292-297

590 Zhao, M., Running S.W., 2010. Drought-induced reduction in global terrestrial net primary production 591 from 2000 through 2009. Science 329, 940-943

592 Zweifel, R., Rigling, A. Dobbertin, M., 2009. Species - specific stomatal response of trees to drought-a 593 link to vegetation dynamics? Jour. Veg. Sci. 20, 442-454. 
Table 1: Characteristics of the study sites

\begin{tabular}{|c|c|c|c|c|}
\hline Forest name & SUMO & Sevilleta & Puechabon & Pfynwald \\
\hline Country & USA & USA & France & Switzerland \\
\hline Latitude/Longitude & $35.49^{\circ} \mathrm{N}, 106.18^{\circ} \mathrm{W}$ & $34.23^{\circ} \mathrm{N}, 106.32^{\circ} \mathrm{W}$ & $43.44^{\circ} \mathrm{N}, 3.35^{\circ} \mathrm{E}$ & $46.19^{\circ} \mathrm{N}, 7.6^{\circ} \mathrm{E}$ \\
\hline Climate & Semi-arid & Semi-arid & Mediterranean & Dry inner-Alpine \\
\hline Forest type & $\begin{array}{l}\text { Piñon-Juniper } \\
\text { woodland }\end{array}$ & $\begin{array}{l}\text { Piñon-Juniper } \\
\text { woodland }\end{array}$ & $\begin{array}{l}\text { Mediterranean oak } \\
\text { evergreen }\end{array}$ & $\begin{array}{c}\text { Mountainous Scots Pine } \\
\text { evergreen }\end{array}$ \\
\hline$M A T^{*}\left({ }^{\circ} \mathrm{C}\right), M A P^{*}(\mathrm{~mm})$ & $9.2,415$ & $12.7,358$ & $13.2,916$ & $9.2,657$ \\
\hline Topography & Light steep & Flat to steep & Flat & Flat \\
\hline Soil depth $(\mathrm{cm})$ & 55 & 20 to 100 & 450 & 500 \\
\hline Elevation (m) & 2175 & 1911 & 270 & 615 \\
\hline Number of target species & 2 & 2 & 1 & 1 \\
\hline \multicolumn{4}{|l|}{ manipulation } & $+80 \%$ \\
\hline Study year & 2016 & 2010 & 2009 & 2014 \\
\hline \multicolumn{4}{|l|}{ before measurements } & 11 years \\
\hline Mean $L A I^{*}\left(m^{2} m^{-2}\right)$ & 1.5 & 0.85 & 2 & 2.1 \\
\hline \multirow[t]{6}{*}{ References } & Adams et al., 2015 & & & Mencuccini et al., 2017 \\
\hline & Grossiord et al., 2016a & & & Hartmann et al., 2017 \\
\hline & Grossiord et al., 2016b & Pangle et al., 2012 & Limousin et al., 2009 & Rigling et al., 2013 \\
\hline & Garcia-Forner et al., & Pangle et al., 2015 & Limousin et al., 2010 & Sterck et al., 2012 \\
\hline & 2016 & & Limousin et al., 2012 & Eilmann et al., 2010 \\
\hline & Grossiord et al., 2017 & & & Martinez-Vilalta et al., 2009 \\
\hline
\end{tabular}

\footnotetext{
*MAP, mean annual sum of precipitation; MAT, mean annual temperature; LAI, leaf area index.
} 
Table 2: Characteristics of the study trees.

\begin{tabular}{lccccc}
\hline Forest Name & $\begin{array}{c}\text { Total number of } \\
\text { measured trees }\end{array}$ & $\begin{array}{c}\text { Number of } \\
\text { treatments }\end{array}$ & $\begin{array}{c}\text { Mean tree } \\
\text { height }(\mathbf{m})\end{array}$ & $\begin{array}{c}\text { Mean } \\
\text { DBH* }(\mathbf{c m})\end{array}$ & $\begin{array}{c}\text { Target } \\
\text { species }\end{array}$ \\
\hline SUMO & 24 & 2 & 3.5 & 13.7 & Piñon/Juniper \\
Sevilleta & 42 & 3 & 4.0 & 27.1 & Piñon/Juniper \\
Puechabon & 11 & 2 & 4.5 & 11.5 & Holm oak \\
Pfynwald & 11 & 2 & 12.0 & 28 & Scots pine \\
\hline
\end{tabular}

*DBH, diameter at breast height. 


\section{Figure legends}

601 Figure 1: Hypothetical relationships between sap flux and daily soil moisture or vapor pressure deficit $602(V P D)$ variation under different long-term soil moisture conditions (high, medium and low soil 603 moisture). The red arrow indicates changes in sap flux sensitivity to soil moisture and $V P D$ resulting 604 from physiological and possible structural adjustments to soil moisture change (e.g. hydraulic resistance, 605 stomatal density, synthesis of chemicals inducing stomatal closure, rooting depth). Because of 606 adjustments to reduced soil moisture, trees would experience a decreased sensitivity to daily soil 607 moisture and $V P D$ variation inducing lower sap flux under both high and low soil moisture status, and 608 lower maximum sap flux under optimal $V P D$. Sensitivity to soil moisture would thus be reflected 609 through changes in the slope of the linear relationship between sap flux and soil moisture while changes 610 in $V P D$ sensitivity would be reflected in shifts of maximum sap flux at optimal $V P D$ (location of the 611 vertex of the curve).

612 Figure 2: Daily variations in atmospheric temperature $\left({ }^{\circ} \mathrm{C}\right)$ and vapor pressure deficit $(V P D, \mathrm{kPa})$ at 613 each site for the selected years.

614 Figure 3: Daily relative extractable water ( $R E W$, unitless) simulated with the BILJOU water balance 615 model for each treatment at each site for the selected years (Table 1). The grey areas correspond to 616 periods where irrigation was ongoing at the SEV and PFY sites. Reduction in incoming precipitation 617 was ongoing all year long in all sites.

618 Figure 4: Relationships between mean daily sap flux density $\left(F_{D}, \mathrm{~g} \mathrm{~m}^{-2} \mathrm{~s}^{-1}\right)$ (individual tree data), and 619 simulated relative extractable water ( $R E W$, unitless) or vapor pressure deficit $(V P D, \mathrm{kPa})$ under ambient, 620 soil moisture addition and soil moisture reduction conditions across all sites. The bold lines represent the 621 fitted linear (i.e. for $R E W$ ) and parabolic (i.e. for $V P D$ ) relationships for each treatment across all sites. 622 Individual sites are not identified for representation purposes. 
624 Figure 5: Sensitivity of $F_{D}$ to simulated $R E W\left(S_{R E W}\right)$ and to $V P D\left(F_{D M a x}\right)$ with standard errors of the 625 mean under ambient, soil moisture addition and soil moisture reduction conditions in each site (PFY $=$ 626 Mountainous coniferous forest, $\mathrm{PUE}=$ Mediterranean evergreen forest, $\mathrm{SEV}$ and SUM $=$ semi-arid 627 forest types). Sites are ordered along the $\mathrm{x}$-axis by soil moisture manipulation intensity going from the 628 highest irrigation to the highest soil moisture reduction site.

629 Figure 6: Relative change in the sensitivity of $F_{D}$ to simulated $R E W$ between ambient and treatment 630 conditions $\left(S_{R E W}\right.$ in the manipulative treatment / $\left.S_{R E W \_A m b i e n t}\right)$, and relative change in the maximum sap 631 flux density at optimum $V P D$ between ambient and treatment conditions $\left(F_{D M a x}\right.$ in the manipulative 632 treatment $\left./ F_{\text {DMax_Ambient }}\right)$ as a function of the relative change in relative extractable water between 633 ambient and treatment conditions during the measurements ( $R E W$ in the manipulative treatment $\left.634 / R E W_{\text {Ambient }}\right)$. Every data point represents the difference between mean ambient conditions (for each site) 635 and an individual tree under treatment conditions (at the same site). 

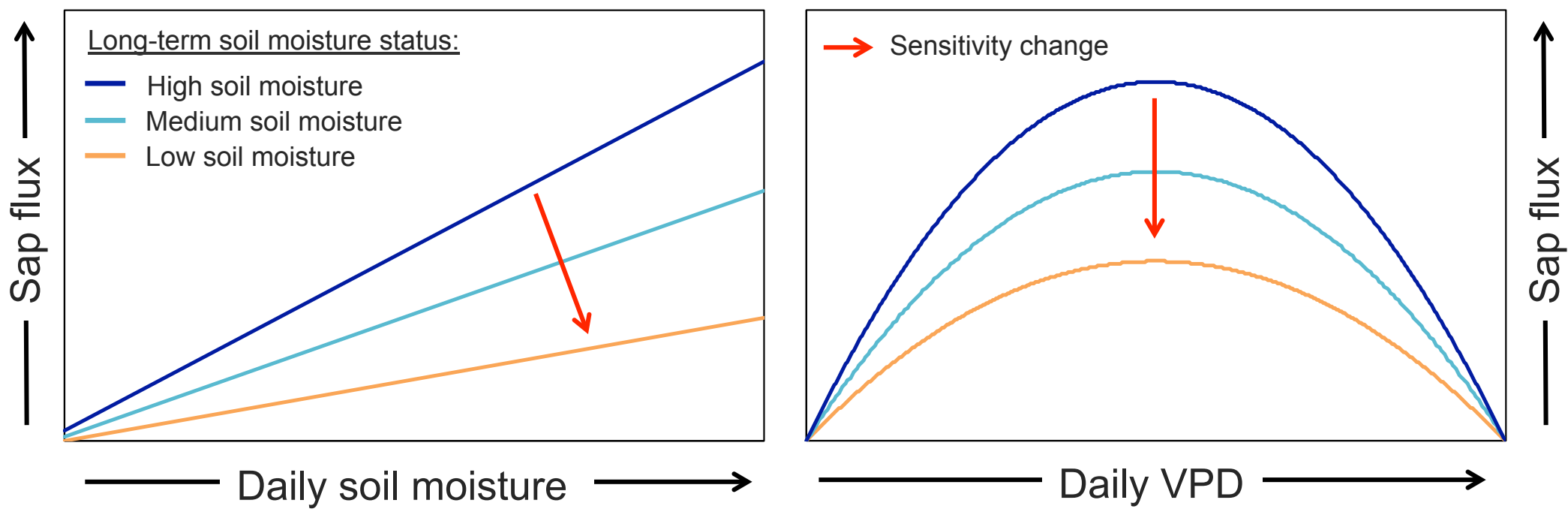

Figure 1: Hypothetical relationships between sap flux and daily soil moisture or vapor pressure deficit $(V P D)$ variation under different

640 long-term soil moisture conditions (high, medium and low soil moisture). The red arrow indicates changes in sap flux sensitivity to

641 soil moisture and $V P D$ resulting from physiological and possible structural adjustments to soil moisture change (e.g. hydraulic resistance, stomatal density, synthesis of chemicals inducing stomatal closure, rooting depth). Because of adjustments to reduced soil moisture, trees would experience a decreased sensitivity to daily soil moisture and $V P D$ variation inducing lower sap flux under both

644 high and low soil moisture status, and lower maximum sap flux under optimal VPD. Sensitivity to soil moisture would thus be

645 reflected through changes in the slope of the linear relationship between sap flux and soil moisture while changes in $V P D$ sensitivity

646 would be reflected in shifts of maximum sap flux at optimal VPD (location of the vertex of the curve). 

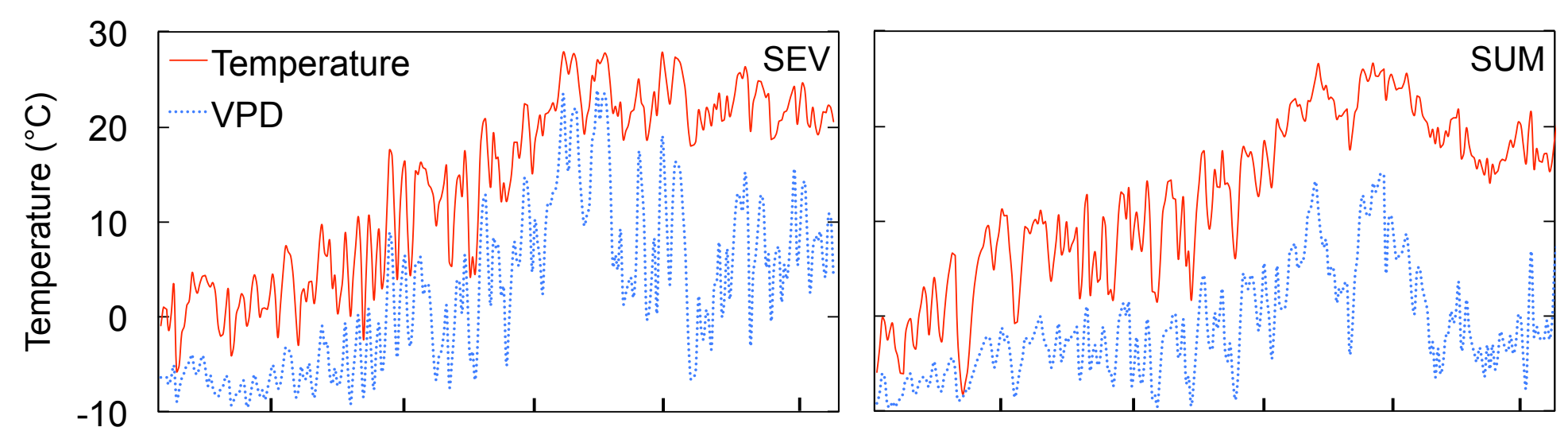

4
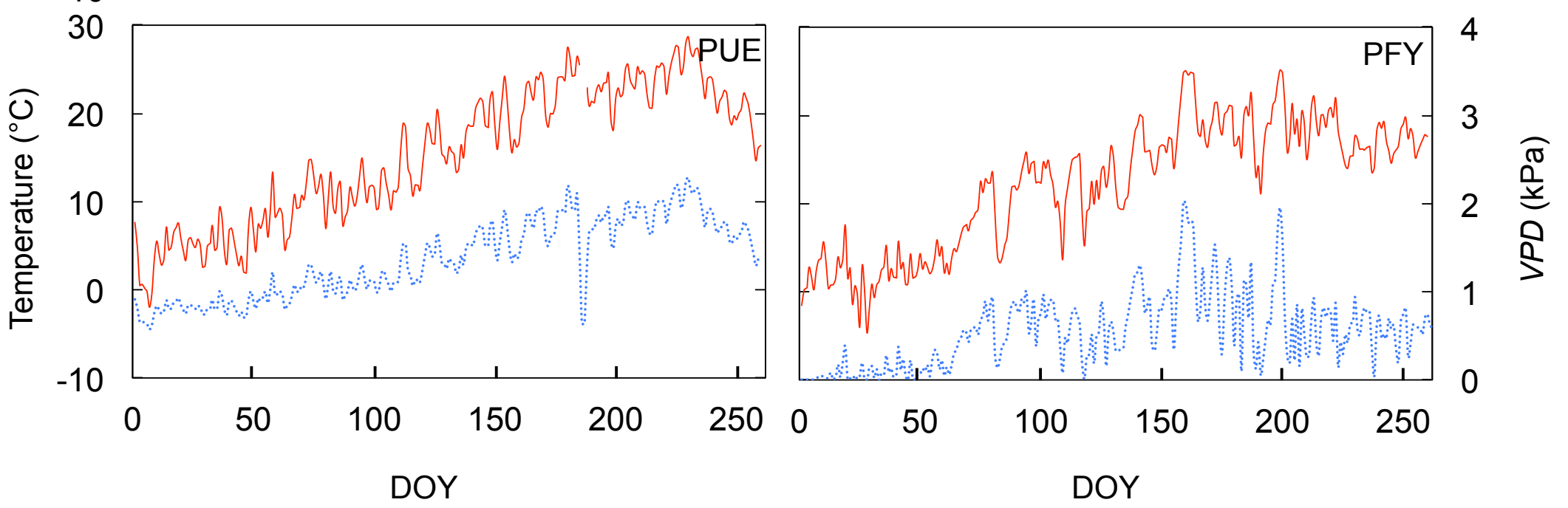

648

649 Figure 2: Daily variations in atmospheric temperature $\left({ }^{\circ} \mathrm{C}\right)$ and vapor pressure deficit $(V P D, \mathrm{kPa})$ at each site for the selected years. 


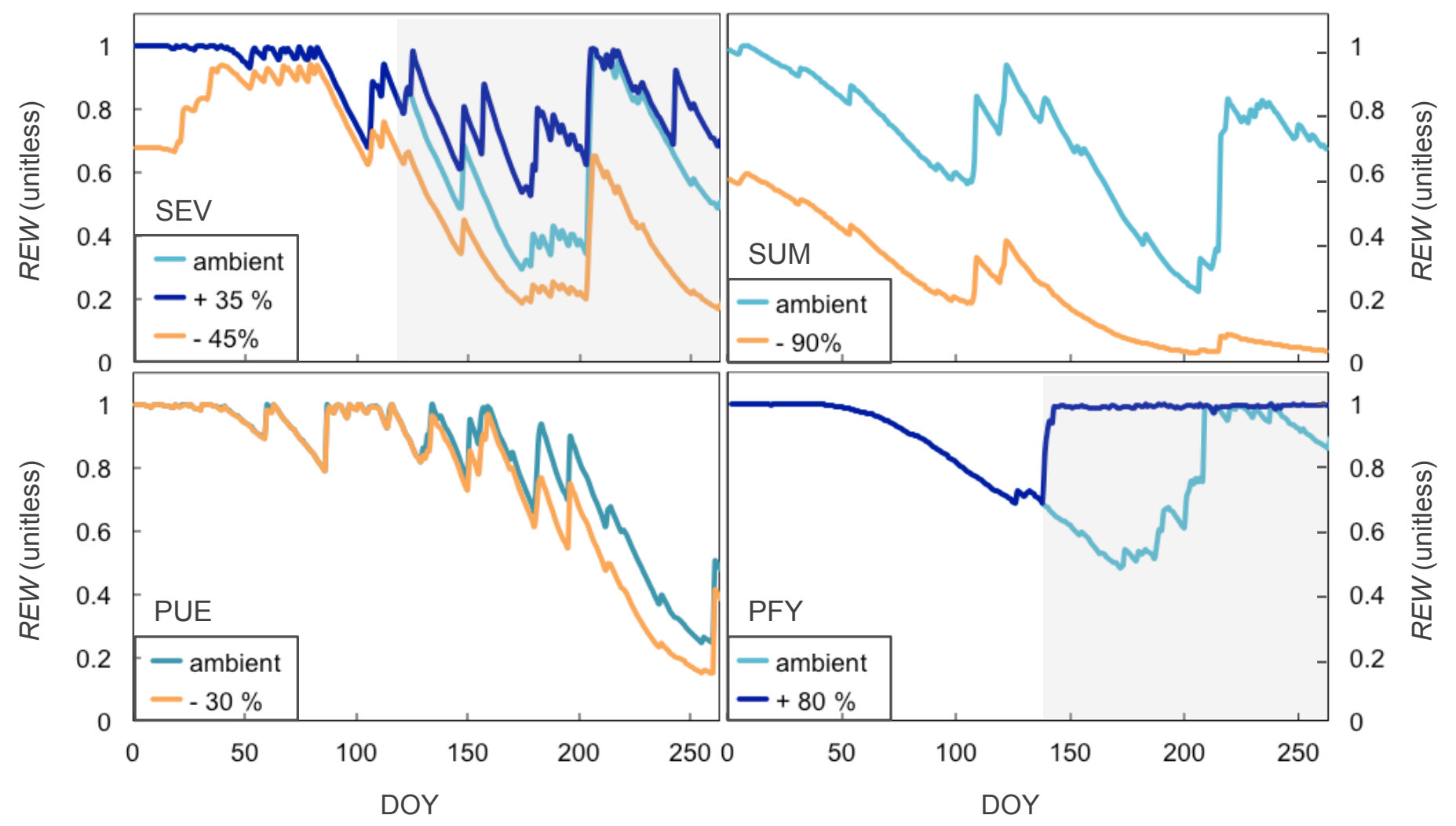

654

655 Figure 3: Daily relative extractable water $(R E W$, unitless) simulated with the BILJOU water balance model for each treatment at each

656 site for the selected years (Table 1). The grey areas correspond to periods where irrigation was ongoing at the SEV and PFY sites.

657 Reduction in incoming precipitation was ongoing all year long in all sites. 


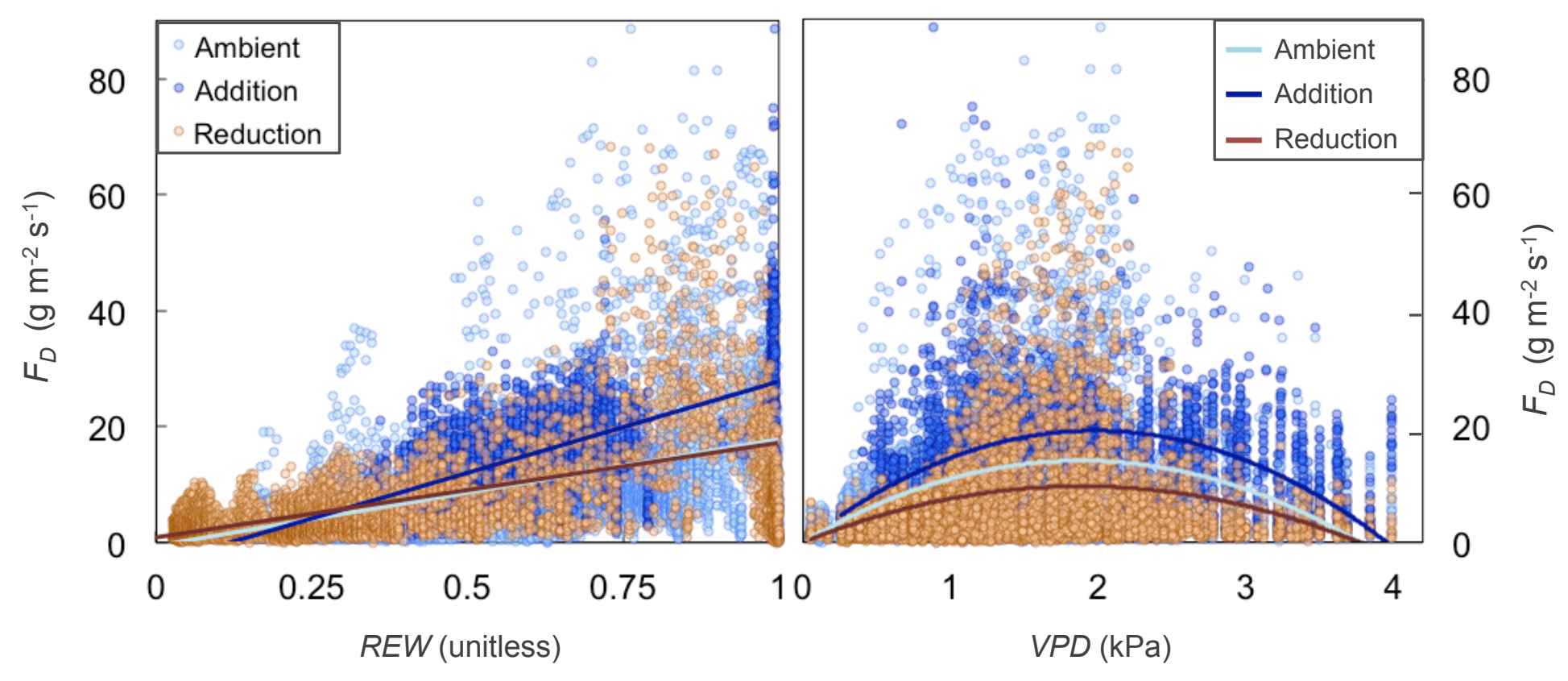

658

659 Figure 4: Relationships between mean daily sap flux density $\left(F_{D}, \mathrm{~g} \mathrm{~m}^{-2} \mathrm{~s}^{-1}\right)$ (individual tree data), and simulated relative extractable

660 water $(R E W$, unitless) or vapor pressure deficit $(V P D, \mathrm{kPa})$ under ambient, soil moisture addition and soil moisture reduction

661 conditions across all sites. The bold lines represent the fitted linear (i.e. for $R E W$ ) and parabolic (i.e. for $V P D$ ) relationships for each

662 treatment across all sites. Individual sites are not identified for representation purposes.

663 


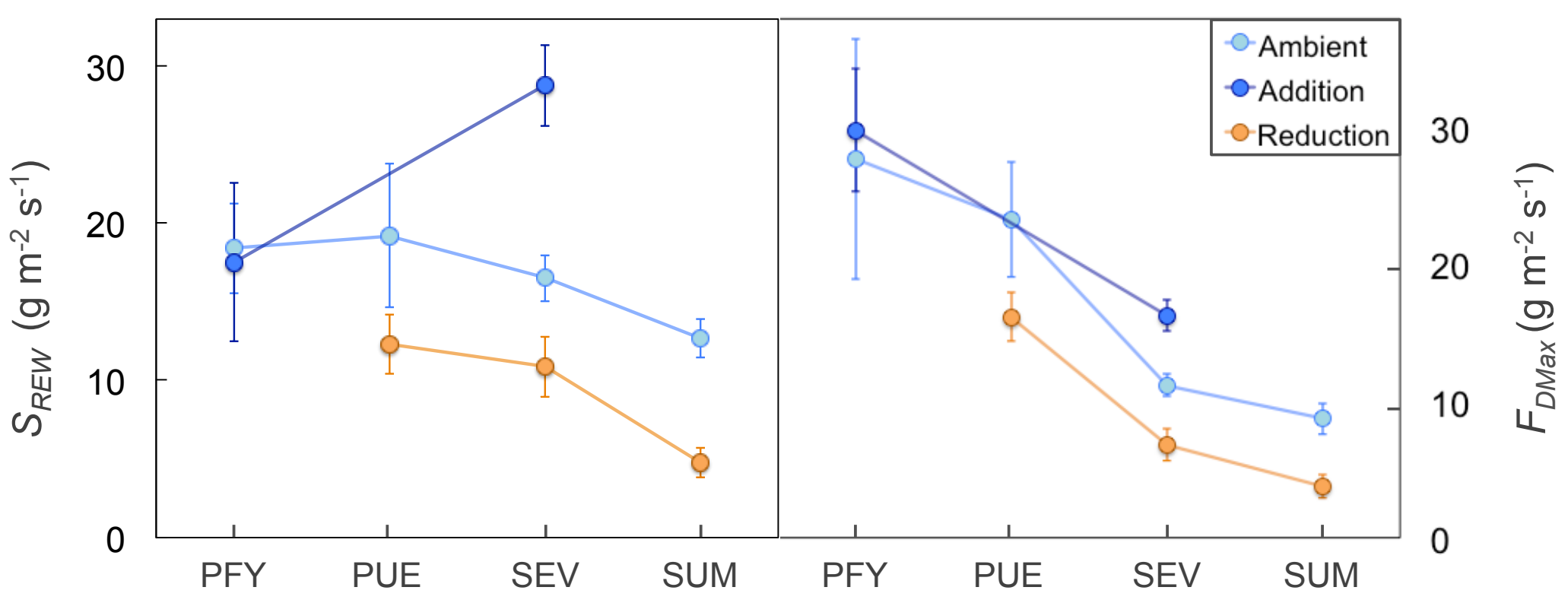

667

668 Figure 5: Sensitivity of $F_{D}$ to simulated $R E W\left(S_{R E W}\right)$ and to $\operatorname{VPD}\left(F_{D M a x}\right)$ with standard errors of the mean under ambient, soil

671 going from the highest irrigation to the highest soil moisture reduction site. 


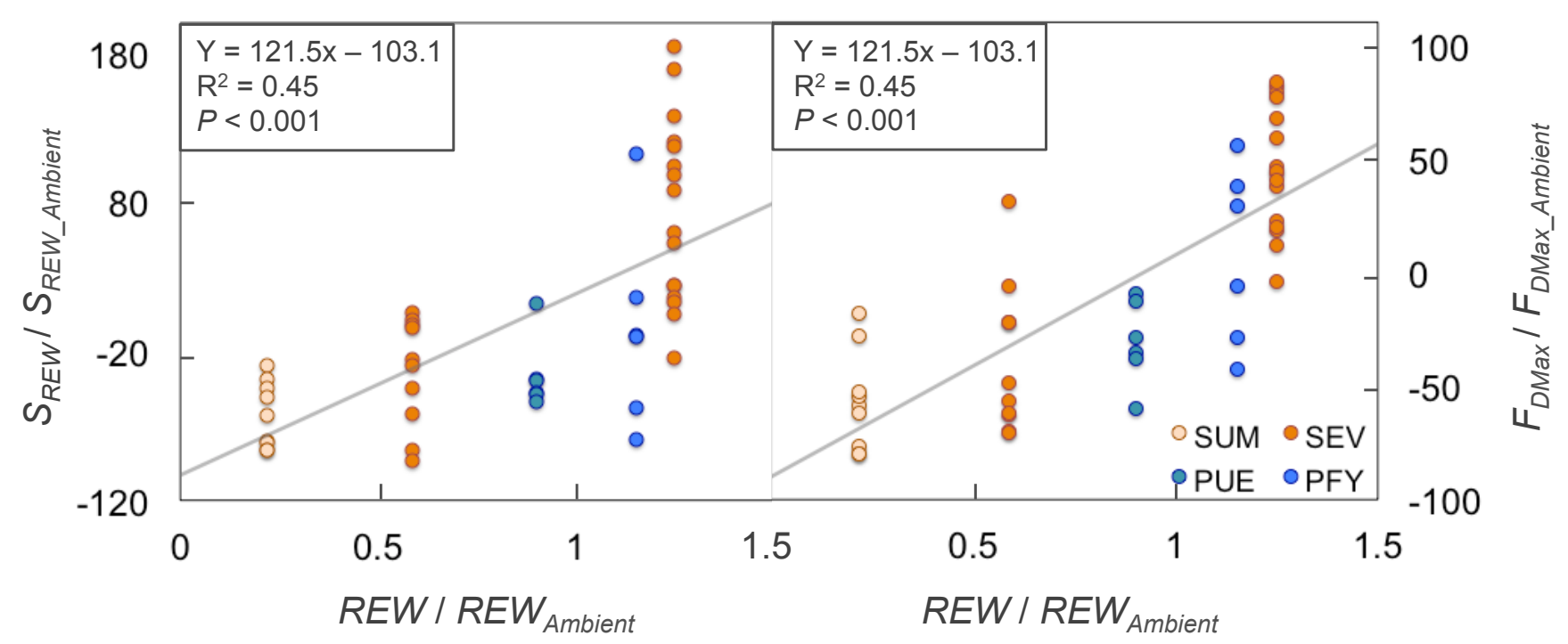

Figure 6: Relative change in the sensitivity of $F_{D}$ to simulated $R E W$ between ambient and treatment conditions $\left(S_{R E W}\right.$ in the manipulative treatment / $\left.S_{R E W_{-} \text {Ambient }}\right)$, and relative change in the maximum sap flux density at optimum $V P D$ between ambient and treatment conditions $\left(F_{D M a x}\right.$ in the manipulative treatment $\left(F_{\text {DMax_Ambient }}\right)$ as a function of the relative change in relative extractable water between ambient and treatment conditions during the measurements ( $R E W$ in the manipulative treatment $\left./ R E W_{\text {Ambient }}\right)$. Every data point represents the difference between mean ambient conditions (for each site) and an individual tree under treatment conditions (at the same site). 